\title{
EU Preferential Trading Arrangements with the Caribbean: A Grim Regional Economic Partnership Agreements?
}

\author{
David Greenaway and Chris Milner \\ University of Nottingham
}

\begin{abstract}
The European Union (EU) has more preferential trading arrangements than any other trading entity. For a quarter of a century African, Caribbean and Pacific $(A C P)$ countries have benefited from unreciprocated preferential access to the $E U$ market under a succession of Lomé Arrangements. Sunset provisions now apply to these concessions and after 2007 unreciprocated preferences will end. The EU is proposing that a network of regional Economic Partnership Agreements (REPAs) replace Lomé. This is a new form of regional trading arrangement for both the EU and ACP countries. In this paper we develop an analytical framework for evaluating the impact effects of a REPA and apply this to estimate costs and benefits in the CARICOM region. Our results suggest that a REPA would be inferior on welfare grounds to either extended reciprocity with the EU and US, or broader multilateral liberalisation.
\end{abstract}

- JEL classification: F15

- Keywords: EU preferences, Partnership agreements

\section{Introduction}

The literature on preferential trading arrangements has grown dramatically over the last decade or so, stimulated by two systemic developments in the global trading environment: the 'new regionalism' and the realignment of a range of special and

\footnotetext{
*Corresponding address: University of Nottingham, Nottingham NG7 2RD, UK. Tel. +44 (0)115 9515469. Fax +44 (0)115 9515552, E-mail: david.greenaway@nottingham.ac.uk, chris.milner@nottingham.ac.uk (C2006-Center for International Economics, Sejong Institution, All Rights Reserved.
} 
differential provisions attached to trade with developing countries. The former has seen exponential growth in the number of free trade areas and provoked an extensive debate on the complementarity of multilateralism and regionalism. ${ }^{1}$ In the case of special and differential treatment of developing countries, changes have been triggered by a combination of revisions to multilateral provisions under the Uruguay Round agreements and bilateral revisions following from individual countries being deemed to have 'graduated'.

Since its creation, the European Union has notified the WTO of more preferential trading arrangements than any other single trading entity. One of the most extensive and long lasting of these is the Lomé Agreements, whereby over 70 African, Caribbean and Pacific (ACP) countries have benefited from preferential access to the European Union (EU). ${ }^{3}$ A key feature of the Agreements is that access has been offered on a non-reciprocal basis since the first Lomé Agreement in 1975. But that is about to change following the successful challenge by the US to the WTO that the Lomé Convention conferred an unfair trading advantage to ACP countries over other WTO Members. Lomé IV (which was signed in 1990), formally ended in February 2000, but the WTO waiver on reciprocity was extended to 2007. After that date, it is a WTO expectation that any EU arrange-ments which replace Lomé will incorporate a reciprocity obligation.

Since 1996 the European Commission has been in negotiations with ACP countries over the post-Lomé environment. Winters (1997) describes these as confronting ACP countries with a 'diabolical trilemma': maintain the status quo (which would have been unacceptable to WTO); accept a straightforward removal of preferences; or accept reciprocal trading arrangements. Discussions concluded with the Contonou Agreement in 1998, which came into force in June 2000 and was as all encompassing as its Lomé predecessors. However, although it extended the period for unreciprocated preferences, it obliged ACP countries to begin negotiations on so called Regional Economic Partnership Agreements (REPAs) no later than 2002, for implementation in 2008. Negotiations on regional EPAs are still ongoing with a number of groups of developing countries clustered on a

\footnotetext{
${ }^{1}$ For a comprehensive survey of the issues see Bhagwati, Greenaway and Panagariya (1998) and a recent analysis of the potential for RTAs to undermine multilateralism see Bond, Riezman and Syropoulos (2004).

${ }^{2}$ See Whalley, 1989 and 1999 for reviews of these issues.

${ }^{3}$ For excellent reviews of EU preferential arrangements with developing countries more generally, see Panagariya (2002) and Francois, McQueen and Wignaraja (2005).
} 
geographic basis.

The key distinctive feature of REPAs is that preferential access to EU markets is mirrored by preferential access to ACP markets for EU exporters. This is a new departure and raises an obvious question from an ACP standpoint: would this freeing of bilateral imports leave them better off? McQueen (1998) and Winters (2001a) conclude almost certainly not. From a policy perspective it is clearly an important issue, not only in the context of the ongoing debate on the complementarity of regionalism and multilateralism but also in the context of the net benefits of preferential trading agreements. It represents a marked shift in policy and poses an as yet under-explored economic issue.

In this paper we develop an analytical framework for assessing the economic effects of reciprocated liberalisation of the form envisaged by a REPA. The framework builds upon Vinerian customs union theory and is in the same family of models as Bhagwati and Panagariya (1997), Schiff (1997) and Winters (2001a). We then apply this to a particular sub-set of ACP countries, those that are members of the Caribbean Economic Community, or $\mathrm{CARICOM}^{4}$. This is an interesting case to take, in part because of the number of countries involved, in part because geographical proximity to the US adds an interesting dimension. We use disaggregated trade data to estimate the welfare effects of such a trade policy innovation and compare them with two benchmarks: extended reciprocity with the EU and US and multilateral liberalisation. Finally, we conclude with an overall assessment of the alternatives. The paper makes a contribution to the regional trade policy analysis literature on two counts: first, in developing a framework for evaluating reciprocal preferences between customs unions; second, in generating one of the first estimates of the costs and benefits of a potential REPA in the Caribbean.

\section{Discriminatory Policy and Reciprocity: Analytical Framework}

We explore the CARICOM import side of a potential REPA, and in particular the liberalisation of imports from a specific trading partner like the EU might affect

\footnotetext{
${ }^{4}$ CARICOM was formed in 1973. Its current Members are: Antigua and Barbuda; The Bahamas; Barbados; Belize; Dominica; Grenada; Guyana; Haiti; Jamaica; Montserrat; St Kitts and Nevis; St Lucia; St Vincent and the Grenadines; Suriname; Trinidad and Tobago.

${ }^{5}$ For analyses of regional integration in the Caribbean see Nicholls et al (2000), and El Agraa and Nicholls (1999) and for a review of the implications of regionalism for small island states see Read (2004).
} 
trade, production and customs revenue in the importing region. ${ }^{5}$ Our initial antimonde is assumed to be a prevailing system of non-discriminatory common external tariffs (CETs). Within a partial equilibrium framework we illustrate how the precise effects are sensitive to what is assumed about substitutability between locally produced goods and imports (or between imports from different sources) and cost conditions applying to potential suppliers from within CARICOM. We begin with two alternatives. First, a perfect substitution world, with local exporters supplying within CARICOM under increasing costs and CARICOM represented as a small economy relative to both the EU and rest of the world (ROW). Second, an imperfect substitution world, with local or regional suppliers having increasing costs and both the EU and ROW facing constant costs.

Perfect substitution case: Figure 1 summarises the basic set up for analysing a shift from non-discriminatory to discriminatory external tariffs in a small home country member $(\mathrm{H})$ of a regional trading agreement (RTA). $D_{H}$ represents home demand for imports, $S_{P}$ the partner's supply of exports, and $S_{E U}$ and $S_{R O W}$ the respective export supply functions for the two outside country groupings. We take the more interesting case where $P_{E U}>P_{R O W}$, and where discriminatory trade policies towards outside countries can have both trade creating and diverting effects. We start with an RTA and a non-discriminatory (ad valorem) tariff $(t)$ on extra-regional imports (where $P_{R O W}^{t}=P_{R O W}^{t}(1+t)$ but $P_{E U}^{t}$ is not shown in the case of the higher cost EU supplier). The home country imports $O M_{2}$, with $O M_{1}$ coming from the partner and $M_{1} M_{2}$ from ROW. For simplicity we rule out domestic production capability, which allows us to define home country welfare ( $W$ ) by reference to consumer surplus. Thus $W_{F T A}$ is given by the triangle $A B P^{t}{ }_{R O W}$ plus tariff revenue on extra-regional imports $(a+b)$.

Now assume the RTA introduces a discriminatory tariff. On entering into a REPA, the RTA maintains a tariff on ROW imports but imports from the REPA partner are duty free. The relevant supply price is now $P_{E U}$, with total imports expanding from $O M_{2}$ to $O M_{3}$ and coming wholly from the EU. There are three components of this trade-effect: a consumption-induced trade creation effect $\left(M_{2} M_{3}\right)$; an extra-regional 'trade diversion' effect $\left(M_{1} M_{2}\right)$; and a regional displacement induced 'trade creation' effect $\left(O M_{1}\right)$. The last two need further explanation.

In standard RTA analysis, trade diversion relates to diverting trade from more efficient extra-regional to less efficient intra-regional suppliers. The REPA, however, diverts between extra-regional suppliers, $M_{1} M_{2}$ is imported from the less efficient EU rather than ROW. The resource cost of this is given by $b$, with tariff revenue 
lost being $a+b$. Similarly, in standard analysis trade creation usually describes the displacement of less efficient home production by globally efficient extra-regional production. The REPA however, involves the replacement of intra-regional imports by more (but not necessarily globally) efficient extra-regional imports from the EU. The regional resource-saving on this 'trade-creation' (or source substitution effect) is shown by $c$ in Fig. 1. This and the loss of producer surplus for partner country exporters $(d)$ allows consumer surplus to increase by $c+d$. Thus, the welfare implications are ambiguous, the consumption and trade-creation effects increases but, the trade-diverting effect reduces, welfare i.e. $\Delta W=(c+d+e)-b$. Clearly the more efficient the EU, the smaller the costs of trade-diversion and greater the probability of a welfare-improving REPA. In the limit as $S_{E U} \rightarrow S_{R O W}$, the REPA tends toward the free trade outcome.

Figure 1 captures the three types of trade effects, but there are other possible complications. First, we represent post-REPA imports $O M_{1}$ as displacing intraregional trade because we assume no home production. There may also be displacement of home production by extra-regional (EU) imports. This would be locally (rather than regionally) welfare-raising on efficiency grounds, but the redistribution of any producer surplus is now from home rather than other regional producers to local consumers. Second, Fig. 1 is constructed as an extreme case. Thus, pre-REPA there are imports only from the regional partner or ROW and none from the EU; while post-REPA, the EU becomes the sole source of imports. This would not result if the regional import supply curve $\left(S_{P}\right)$ were constructed so as to cut $S_{E U}$ from below. Similarly some imports from the EU (ROW) may exist pre- (post) REPA if the EU supply were upward sloping, in which case the price of

Figure 1. Effect of an EU-CARICOM REPA with Perfect Substitution

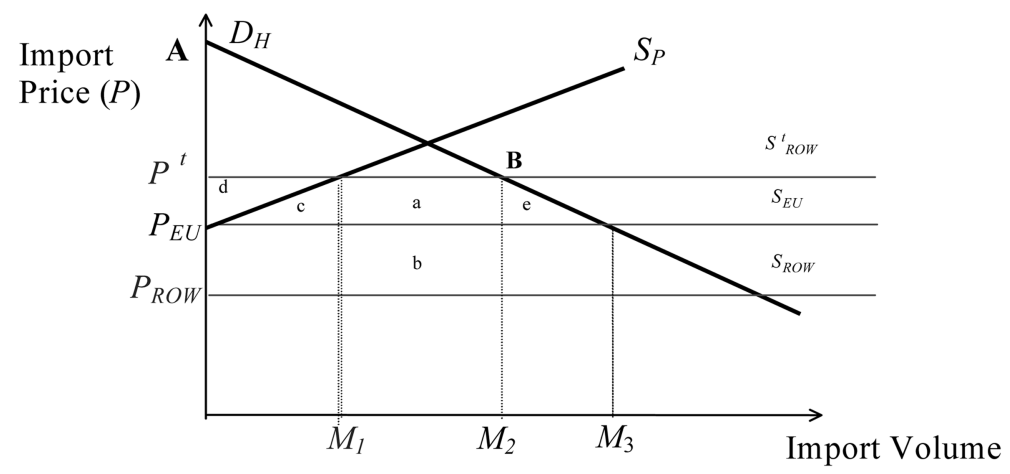


imports to local consumers may or may not fall and there is ambiguity as to the pattern of trade and welfare effects. Note also that this framework creates difficulties for operationalisation, because the "price-effect" of introducing the REPA is ambiguous. With an upward sloping $S_{E U}$ there may be no price-effect. By contrast, as the cost competitiveness of the EU increases and $S_{E U}$ tends to $S_{R O W}$ the price-effect of discriminatory tariff-removal tends to the full amount of the common external tariff. Where the EU is globally efficient it will dominate the regional market before and after the REPA, which is then equivalent to multilateral liberalisation (no trade diversion between extra-regional import sources, only regional/local displacement and consumption expansion).

Local consumers cannot be made worse off by the REPA and will benefit if imports from any source fall in price. Regional producers, however, lose if local prices fall, and there is a decline in regional production. This efficiency gain brings with it adjustment costs to local producers and workers and other potential political economy costs for governments in the host country or regional partner. If there is high fiscal dependence on trade taxes, Governments will also be concerned about trade diversion induced revenue losses.

Imperfect substitution case: For other than highly specific products at a high level of commodity disaggregation it is unrealistic to assume away multiple sources of supply or that the REPA will consistently divert all imports to EU sources. If we want to retain the constant cost assumption for the EU it may be more appropriate to relax another assumption, that of undifferentiated products. Given differences in technologies and tastes, one might view imports in a particular category as differentiated by source. In our framework goods produced in the region can be seen as differentiated from extra-regional imports, and EU imported varieties as differentiated from ROW varieties. Fig. 2 illustrates this. For convenience, we assume all regions are constant and equal cost suppliers. PreREPA import prices in market $H$ are $P_{B} P_{R O W}(1+t)$ and $P_{E U}(1+t)$. The corresponding import volumes are $O M_{1}, O M_{2}$ and $O M_{3}$. Following the REPA the new equilibrium for EU varieties shifts to the price-quantity combination of $P_{E U}$ and $O M_{3}$. This increase in imports from the EU is analogous to the consumptioninduced trade creation effect described earlier, with consumer welfare gains represented by $e$. In the other segments of the market, the fall in price to local consumers of EU imports implies an increase in relative prices of imports from other sources. $D_{H}^{P}$ and $D_{H}^{R O W}$ shift inwards to $D_{H}^{P^{\prime}}$ and $D_{H}^{R O W}$ respectively. The 
Figure 2. Effect of an EU-Caricom Repa with Imperfect Substitution ${ }^{(1)}$
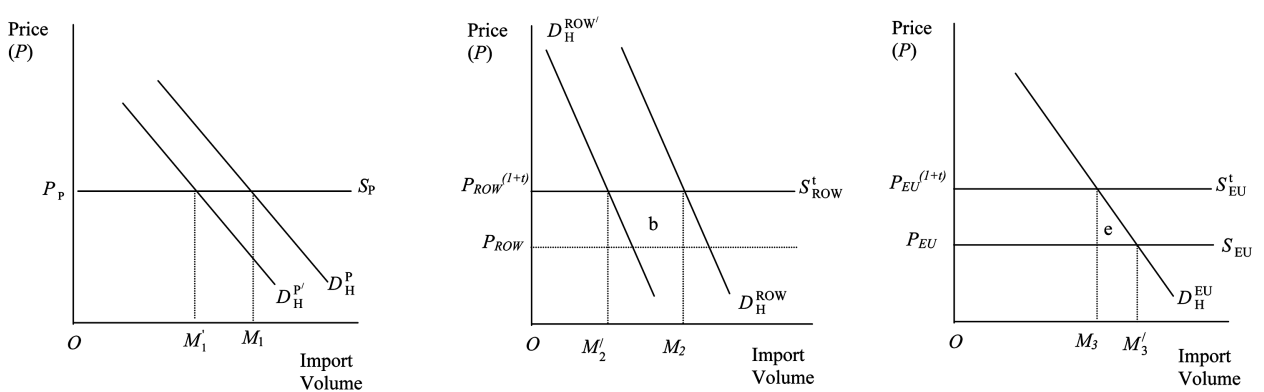

${ }^{*} D_{H}^{E U}$ is constructed to represent only the direct consumption induced, trade creation effect of the fall in price of EU imports

(1) Note that imperfect substitution means that $P_{P}=P_{R O W}=P_{E U}$ no longer necessarily holds. The pattern of prices shown, however, is by construction, allowing simplification of the empirical analysis given data constraints.

volume of imports from ROW contracts from $\mathrm{OM}_{2}$ to $\mathrm{OM}_{2}$ and this captures the trade diversion effect. As with perfect substitution this results in a fall in customs revenue of $b$ in Fig. $2^{6}$

Intra-regional imports again shift towards EU sources, falling from $O M_{1}$ to $O M_{1}$ with $M_{1} M_{1}$ analogous to the displacement of regional production described in the perfect substitution case. This will directly involve declines in regional production, employment and producer rents. The welfare effects are however less clear cut. Neither $D_{H}^{P}$ nor $D_{H}^{P}$ represent demand for regional varieties when there is uniform taxation of imports from all sources.

\section{Empirical Modelling}

We adopt the imperfect substitution modelling strategy which allows for imports to any member of the RTA from other members, the ROW and EU. ${ }^{7}$ In line with Fig 2, we label these, type 1, 2 and 3 imports respectively. Thus $\Delta M_{i}$ will measure the change in the volume of imports from area $i$ as a result of a policy experiment/

\footnotetext{
${ }^{6}$ (Note that we are viewing EU and ROW producers as competitive, i.e. competing with each other to supply the CARICOM market. This means that there are no monopoly profits outside of the region, which would complicate the welfare analysis.)

${ }^{7}$ Milner, Morrissey and McKay (2005) apply a perfect substitution approach to the analysis of an economic partnership agreement between the EU and East African Cooperation (EAC) countries. In that case sectors have to be categorised according to the dominant source of supply ie as if imports did exist from all sources. The imperfect substitution approach used here overcomes this problem
} 
simulation: $\Delta M_{1}(\mathrm{CARICOM}), \Delta M_{2}(\mathrm{ROW})$, and $\Delta M_{3}(\mathrm{EU})$. With a REPA $\Delta M_{1}$ and $\Delta M_{2}$ directly capture any substitution of import source from regions 1 and 2 to the EU. Strictly this should be included in $\Delta M_{3}$, but for presentational convenience we restrict $\Delta M_{3}$ to direct consumption-induced trade creation effects from the EU (as in Fig. 2). We can estimate this consumption effect in value terms, setting all tariff prices to unity by reference to the existing import levels from the EU as ${ }^{8}$ :

$$
\Delta M_{3}=\frac{-t}{1+t} \cdot e_{M}^{D} \cdot M_{3}
$$

where $e_{M}^{D}=$ elasticity of demand for imports

$t=$ pre-REPA tariffs applied to imports from region 3 (EU)

$M_{3}=$ pre-REPA value of imports from region $3(\mathrm{EU})$

For trade creation induced displacement of regional trade $\left(\Delta M_{1}\right)$ or trade diversion displacement of the source of extra-regional trade $\left(\Delta M_{2}\right)$, the extent of import source-substitution for an initial level of imports from region 3 can be approximated $^{9}$ via the elasticity of import substitution as:

$$
\begin{gathered}
\Delta M_{i}=\frac{-t}{1+t} \cdot \sigma_{i 3} \cdot M_{i} \\
{[i=1,2]}
\end{gathered}
$$

where $\sigma_{\mathrm{i} 3}=$ elasticity of import substitution between imports from region $i$ and 3 (EU)

$$
M_{i}=\text { initial pre-REPA relative import levels }
$$

Displacement of intra- by extra-regional imports involves no loss of customs revenue. Trade diversion, (extra-regional trade source substitution) does however induce a fiscal effect. Continuing to set import prices to unity, we can estimate this as:

\footnotetext{
${ }^{8}$ This simplification is necessitated by the absence of disaggregated volume and therefore price (unit value) data. It will induce some biases in the estimates, especially at the disaggregate level.

${ }^{9}$ The assumption of constant costs is also convenient for the empirics. It is a more reasonable assumption for region 2 (ROW) than region 1 (CARICOM). With increasing costs, the lowering of the EU tariff will reduce both the quantity and price of imports from CARICOM sources. The present methodology therefore may tend to understate in value terms the scale of substitution from CARICOM to EU suppliers.
} 


$$
\Delta R=t . \Delta M_{2}-t M_{3}^{0}
$$

where $\Delta M_{2}=$ change in value of imports from source 2 (ROW) due to REPA $M_{3}^{0}=$ initial or pre-REPA level of imports from region 3 (EU)

As we have seen, welfare effects differ between perfect and imperfect substitution cases. For empirical purposes, we utilise the latter and therefore exclude any quantitative welfare assessment of intra-regional trade displacement. Clearly there will be a tendency to redistribute from producers to consumers within the region but we may be understating potential gains from trade creation in the event of perfect substitution. There may also be a tendency for the imperfect substitution case to overstate costs of trade diversion by recording all customs revenue losses as welfare losses. With perfect substitution some revenue loss will be offset by consumer gains from lower prices. Subject to these caveats we estimate the net welfare $(W)$ effects of (extra-regional) trade creation and diversion represented by $e$ $+b$ in Fig. 2 as: -

$$
\Delta W=\frac{1}{2} t\left(\Delta M_{3}\right)+\Delta R
$$

where $\Delta M_{3}$ is given by eq. (1)

$\Delta R$ is given by eq. (3)

Equations 1 to 4 are applied to SITC 2 digit trade data for Barbados, Belize, Grenada, Jamaica, St Lucia, Trinidad and St Vincent for 1998 and Dominica, St Kitts and Nevis for $1997 .{ }^{10}$ Import demand and substitution elasticities were not available from earlier studies with comprehensive coverage at the level of disaggregation of the present analysis. The required parameters were therefore proxied by estimates widely used in other empirical trade studies. Import demand elasticities $\left(e_{M}^{D}\right)$ were based on Stern et al. (1974) and the import source substitution elasticities $\left(\sigma_{i 3}\right)$ from the Global Trade Analysis Project (GTAP) behavioural parameters file (Hertel et al, 1997). In both cases we assume that the elasticities for a particular product group are the same across CARICOM countries. Import demand elasticities for the 2 digit HS Code were matched up with trade data. The import substitution elasticities also were not in general as disaggregated

\footnotetext{
${ }^{10}$ Note that no data are available for Antigua and Barbuda, Monserrat and Suriname and would have been available for Guyana only for 1994.
} 
as the trade data, with a given GTAP commodity value being allocated to a number of trade categories. Appendix 1 sets out the relevant values used for each SITC 2 digit category. ${ }^{11}$ Given the level of aggregation, we estimated current average tariffs at the 2 digit level of the trade classification for each CARICOM member. These were available only for Trinidad, Jamaica and Barbados. In all these cases some matching of data for differences in classification with the trade data was required. The average tariffs which resulted from this are also set out in Appendix 1.

The above partial equilibrium methodology can be applied to fairly disaggregated trade and tariff data, and at a level that would allow trade negotiations to identify key or sensitive import categories where significant trade or revenue impacts occur; categories that might in practice be excluded from the reforms or might be subject to longer transitional arrangements. It must of course be acknowledged that the resulting estimated effects are impact effects only, which abstract from longer term effects associated with income and general equilibrium adjustments.

\section{Trade, Welfare and Fiscal Effects of REPA Reciprocity}

Trade Effects: For each of the 9 CARICOM countries the change in the value of imports $\left(\Delta M_{i}\right)$ in each 2 digit category is estimated as:

i) intra-regional to extra-regional (EU) import substitution $\left(\Delta M_{1}=\right.$ change in imports from CARICOM sources)

ii) extra-regional import substitution from ROW to EU ( $\Delta M_{2}=$ change in imports from ROW)

iii) extra-regional (EU) import consumption or trade creation $\left(\Delta M_{3}=\right.$ direct change in imports from EU)

iv) the total increase in imports from the $\mathrm{EU}\left(\Delta M=\left|\Delta M_{1}\right|+\left|\Delta M_{2}\right|+\Delta M_{3}\right)$

We first aggregate these values across all import categories, and report them in Table 1. The direct consumption or trade creation effect of a lower tariff on EU imports is shown in column (a). Percentage increases range from $12.2 \%$ in Trinidad

\footnotetext{
${ }^{11}$ Note that this study uses what GTAP describes as the domestic to imported goods elasticity as the regional to extra-regional IMPORT substitution elasticity (i.e. $\sigma 13$ in eq. 2), with the extra-regional source elasticities (i.e. $\sigma 23$ in eq. 2) set at twice the value of regional to extra-regional elasticity. Differences in preferences or technologies between the region and outside of the region, combined with a tendency to prefer or protect local products, are usually used to defend this differential.
} 
Table 1. Import Effects ${ }^{(1)}$ of Reciprocity EU Only (By Country)

\begin{tabular}{|c|c|c|c|c|c|c|c|c|c|c|c|c|}
\hline & \multicolumn{2}{|c|}{\begin{tabular}{|c|} 
(a) \\
Trade creation \\
on existing EU imports
\end{tabular}} & \multicolumn{2}{|c|}{$\begin{array}{c}\text { (b) } \\
\text { Change in imports } \\
\text { from Region }\end{array}$} & \multicolumn{2}{|c|}{$\begin{array}{l}\text { (c) } \\
\text { Change in imports } \\
\text { from Non-EU ROW }\end{array}$} & \multicolumn{2}{|c|}{$\begin{array}{c}(\mathrm{d}) \\
\text { Total Increase in } \\
\text { Imports from EU }\end{array}$} & \multicolumn{2}{|c|}{$\begin{array}{c}\text { (e) } \\
\text { Increase in } \\
\text { Extra-regional Imports }\end{array}$} & \multicolumn{2}{|c|}{$\begin{array}{l}(\mathrm{f}) \\
\text { Increase in imports } \\
\text { from all sources }\end{array}$} \\
\hline & $\mathrm{m} \mathrm{ECS}$ & $\%$ & $\mathrm{~m} \mathrm{ECS}$ & $\%$ & m EC\$ & $\%$ & m EC\$ & $\%$ & m ECS & \% & $\mathrm{m} \mathrm{ECS}$ & $\%$ \\
\hline Belize & 11.61 & 15.7 & -7.39 & -25.8 & -328.88 & -48.2 & 347.88 & 471.7 & 19.00 & 2.5 & 11.61 & 1.5 \\
\hline Dominica & 8.60 & 15.4 & -23.96 & -25.6 & -111.83 & -52.2 & 144.39 & 259.3 & 32.56 & 12.1 & 8.60 & 2.4 \\
\hline Kitts\&Nevis & 6.94 & 15.0 & -17.70 & -23.6 & -149.28 & -54.2 & 173.92 & 376.6 & 24.64 & 7.7 & 6.94 & 1.8 \\
\hline St. Lucia & 21.33 & 15.3 & -49.51 & -26.0 & -305.09 & -54.9 & 375.94 & 269.2 & 70.85 & 10.2 & 21.34 & 2.4 \\
\hline Trinidad & 160.85 & 12.2 & -69.08 & -24.4 & -2619.31 & -39.9 & 2849.24 & 215.8 & 229.93 & 2.9 & 160.85 & 2.0 \\
\hline St. Vincent & 16.30 & 14.7 & -33.11 & -26.0 & -135.84 & -48.4 & 185.25 & 167.1 & 49.41 & 12.6 & 16.30 & 3.1 \\
\hline
\end{tabular}


to $15.8 \%$ for Jamaica. ${ }^{12}$ Estimated source substitution effects are reported in columns (b) and (c). They are much larger in absolute terms in the case of extraregional substitution, partly because more trade is involved and because higher substitution elasticites were imposed. The percentage decline in imports from the ROW ranges from $39.9 \%$ for Trinidad to $56.9 \%$ for Jamaica. With trade substitution from this source valued at over EC $\$ 8000$ mill for these 9 countries there are clearly considerable opportunities for increased exports by the EU associated with full reciprocity. This improved market access increases further when we sum across columns a), b) and c) to estimate the total increase in imports from the EU, which ranges from 167.1\% in St Vincent to over 500\% for Jamaica.

Note that the regional to extra-regional substitution information in column $b$ ) relates to the regional market rather than regional producers involved i.e. the imports of Barbados from the region are estimated to fall by EC\$92.36 mill. The adjustment impact of this will be felt elsewhere in CARICOM by those countries that previously supplied Barbados. Across the region as a whole the fall in intraregional imports is significant, between $21 \%$ and $28.9 \%$. The remainder of Table 1 draws attention to the source-switching effects, which imply much smaller net effects on total extra-regional imports and on total imports from all sources; the former (column e) increasing from between 2.9\% (Trinidad) to $12.8 \%$ (Grenada) and the latter (column $\mathrm{f}$ ) rising from $1.5 \%$ to $3.1 \%$.

To gain some insight into sectoral adjustments associated with displacement of intra-regional by EU imports, Table 2 reports the breakdown of intra-regional trade

Table 2. Commodity Shares of REPA Induced Decline in Intra-Regional Imports

\begin{tabular}{l|r|r|r|r|r|r|r|r|r}
\hline & \multicolumn{1}{|c}{ SITC Division } \\
\hline Importing Country & \multicolumn{1}{|c|}{0} & \multicolumn{1}{c|}{1} & \multicolumn{1}{c}{2} & \multicolumn{1}{c}{3} & \multicolumn{1}{c}{4} & \multicolumn{1}{c}{5} & \multicolumn{1}{c}{6} & \multicolumn{1}{c}{7} & \multicolumn{1}{c}{8} \\
\hline Barbados & 16.8 & 16.1 & 1.2 & 28.4 & 0.1 & 6.8 & 7.8 & 2.4 & 20.5 \\
Belize & 33 & 11.3 & 0 & 2.4 & 0.8 & 20.1 & 18.7 & 3.3 & 10.4 \\
Dominica & 26.4 & 22.2 & 0.3 & 14.9 & 4.2 & 7.8 & 10.1 & 2.3 & 11.8 \\
Grenada & 22 & 8 & 0.5 & 11.7 & 1 & 8.4 & 31.7 & 2.7 & 14 \\
Jamaica & 29.7 & 18.5 & 0.1 & 20.3 & 3.1 & 16.1 & 6.2 & 0.9 & 5 \\
Kitts\&Nevis & 15.9 & 13.6 & 0.2 & 22.9 & 0.4 & 10.6 & 17.8 & 2.7 & 15.8 \\
St. Lucia & 33.5 & 12.5 & 0.1 & 12.6 & 0.6 & 10.5 & 12.9 & 1.8 & 15.5 \\
Trinidad & 36.1 & 6.6 & 1.1 & 29.3 & 1.4 & 10.1 & 6.7 & 1.9 & 7 \\
St. Vincent & 27.1 & 9.7 & 0.5 & 13 & 1.1 & 10.2 & 19 & 3.6 & 15.8 \\
\hline
\end{tabular}

\footnotetext{
${ }^{12}$ The range in absolute terms is of course much greater, given the variations in import capacity and existing trade with the EU.
} 
effects for each importing country. For Barbados for instance $28.4 \%$ of the EC\$92.36 million total decline is in SITC division 3. Since the manufacturing import categories are SITC divisions 5-8, it is evident that the largest declines are outside manufacturing; in particular in division 0,1 and 3 . There are however substantial declines for some countries in specific manufacturing areas. Indeed, a limited number of import categories account for a considerable proportion of the overall decline in regional imports; for instance 33 (petroleum), 11 (beverages) and 55 (essential oils).

The substitution of extra-regional imports towards the EU does not have immediate implications for regional trade and production, though it does for tax revenue. It is of interest however, to know in what sectors the EU would benefit from increased export opportunities. In Table 3 we report the commodity breakdown of extra-regional trade diversion. Outside Division 0 , the bulk of the scope for substitution from others to EU supplies lies in manufactured products, in particular divisions 7 and 8 .

A similar picture emerges in Table 4 from an analysis of the total increase in imports from the EU. For all of the countries at least $60 \%$ of the increase is in Divisions 0,7 and $8 .^{13}$

Fiscal Effects: Granting full reciprocity to the EU implies forsaking customs duty on existing imports and revenue on imports diverted from extra-regional

Table 3. Shares of Extra-Regional Trade Diversion From EU Reciprocity

\begin{tabular}{l|c|c|c|c|c|c|c|c|c}
\hline & \multicolumn{1}{|c}{ SITC Division } \\
\hline Importing Country & 0 & 1 & 2 & 3 & 4 & 5 & 6 & 7 & 8 \\
\hline Barbados & 13.2 & 1.4 & 2.2 & 1.1 & 0.7 & 5.9 & 9.7 & 38.6 & 27.3 \\
Belize & 20 & 1.5 & 0.2 & 8.7 & 0.9 & 5.6 & 14.1 & 26.4 & 22.6 \\
Dominica & 18.6 & 2.2 & 2.2 & 0.8 & 6.1 & 7.7 & 11.4 & 31.6 & 19.3 \\
Grenada & 20.7 & 1.2 & 1.9 & 0.5 & 0.1 & 4.2 & 13.1 & 39.2 & 19.2 \\
Jamaica & 21.8 & 1.4 & 1.2 & 3.9 & 1.2 & 5.3 & 10.4 & 25.8 & 29 \\
Kitts\&Nevis & 21.8 & 2.7 & 1.7 & 1.1 & 1 & 4.5 & 12.2 & 34 & 21 \\
St. Lucia & 26.1 & 3.1 & 2.2 & 2.8 & 0.1 & 4.6 & 11.6 & 27.7 & 21.8 \\
Trinidad & 15.1 & 1.8 & 1.4 & 13.9 & 1.9 & 4.7 & 15.6 & 36.3 & 9.3 \\
St. Vincent & 29.9 & 0.8 & 3.3 & 0.7 & 0.3 & 4.8 & 14.8 & 25.5 & 19.9 \\
\hline
\end{tabular}

\footnotetext{
${ }^{13}$ Highest growth rates are recorded in a number of key 2 digit categories, namely 84 (clothing), 78 (road vehicles) and 77 (electrical machinery) are consistently important in the manufacturing sector and 1 (meat etc) and 5 (vegetables and fruit) in the agricultural sector.
} 
Table 4. Percentage Breakdown of Increase in Imports from EU

\begin{tabular}{l|c|c|c|c|c|c|c|c|c}
\hline & \multicolumn{1}{|c}{ SITC Division } \\
\hline Importing Country & 0 & 1 & 2 & 3 & 4 & 5 & 6 & 7 & 8 \\
\hline Barbados & 12.9 & 3.1 & 2 & 3.5 & 0.6 & 6.1 & 10 & 36 & 25.8 \\
Belize & 20.5 & 2 & 0.1 & 8.3 & 0.9 & 5.9 & 14.1 & 26.2 & 21.9 \\
Dominica & 20.5 & 5.6 & 1.8 & 3.1 & 5.5 & 7.8 & 11.2 & 26.8 & 17.8 \\
Grenada & 21.3 & 2.5 & 1.6 & 2.4 & 0.3 & 4.9 & 16.3 & 32.8 & 17.9 \\
Jamaica & 22 & 2.5 & 1.1 & 4.8 & 1.3 & 6.1 & 10.3 & 24.8 & 27.1 \\
Kitts\&Nevis & 21.2 & 4 & 1.5 & 3.3 & 0.9 & 5.2 & 13 & 30.6 & 20.4 \\
St. Lucia & 27 & 4.7 & 1.8 & 4 & 0.2 & 5.4 & 12.3 & 24.1 & 20.6 \\
Trinidad & 15.3 & 1.9 & 1.3 & 13.5 & 1.8 & 5.1 & 15.5 & 36.4 & 9.1 \\
St. Vincent & 28.4 & 2.5 & 2.5 & 2.8 & 0.5 & 5.8 & 16 & 23 & 18.5 \\
\hline
\end{tabular}

(dutiable) sources ${ }^{14}$. Taking the actual values of existing imports from the EU and estimated values of diverted extra-regional imports and applying the fall in the tariff rate (from existing levels to zero), we can estimate potential fiscal losses. The estimated revenue declines in Table 5 range from EC $\$ 21.85$ mill (Dominica) to EC $\$ 635.12$ mill (Jamaica). In relative terms the falls in revenue across countries are more similar; from $61.8 \%$ to $78.1 \%$.

Net Welfare and Distributional Effects: As argued earlier, source substitution effects leave net trade unaltered. It is the consumption-expansion effects of lower tariffs on existing EU imports that generate gains for consumers. The extent of this was reported in Table 1. As discussed above, the major sources of potential consumer gain are in the manufacturing divisions (in particular Division 7) or in

Table 5. Summary of Revenue and Welfare Effects of Reciprocity to EU Only

\begin{tabular}{l|c|c|c}
\hline & \multicolumn{2}{|c|}{ Change in Customs Revenue } & Change in Net Welfare \\
\hline & mEC\$ $\$$ & $\%$ & mEC\$ \\
\hline Barbados & -182.43 & -78.1 & -131.71 \\
Belize & -52.33 & -68.0 & -43.5 \\
Dominica & -21.85 & -75.1 & -14.96 \\
Grenada & -31.19 & -74.4 & -21.83 \\
Jamaica & -635.12 & -76.7 & -550.31 \\
Kitts\&Nevis & -25.89 & -73.0 & -20.39 \\
St. Lucia & -60.40 & -76.8 & -42.64 \\
Trinidad & -390.09 & -61.8 & -292.9 \\
St. Vincent & -27.34 & -72.0 & -16.36 \\
\hline
\end{tabular}

\footnotetext{
${ }^{14}$ Nicholls et al (2002) provides an econometric analysis of fiscal effects.
} 
agricultural/food products (Division 1). The impact on producers is not directly identifiable from the present analysis. Strictly, estimated changes in intra-regional imports identify regional, not national, producer losses, and are not part of estimated national welfare effects in the importing countries. They do however give us a guide to the sectors likely to be subject to producer losses, if we assume production structures are similar across the region.

It should be noted that we only include extra-regional trade effects; consumer gains associated with trade creation on existing EU imports less the fiscal losses associated with extra-regional import source substitution (which involves a redistribution from the importing country). The summary net welfare effects are reported in Table 5. These are consistently negative, ranging from EC\$14.96 mill (Dominica) to EC\$550.31 mill (Jamaica). These relatively small net effects mask much larger redistributions; in this case away from regional producers and government revenues.

\section{Estimates of Relative Costs and Benefits for Alternative Trade Policy Benchmarks}

Potential alternatives to a CARICOM-EU REPA are extended reciprocity (conceded to both the EU and US) and full multilateral non-discriminatory liberalisation. To complete our assessment we compare our REPA results to both. They are sensible comparators to take as, in the case of the former, the CBI would almost certainly oblige CARICOM countries immediately to extend preferences to the US; and, in the case of the latter, one can map out plausible and feasible multilateral alternatives to a REPA as Winters (2001a) has done.

In the alternative experiments we take pure cases; restricted reciprocity involving complete removal of tariffs against EU imports; extended reciprocity involving removal of all tariffs against EU and US imports; and non-discrimination represented by the elimination of tariffs on all extra-regional imports. Given that the EU, US and rest of the world (ROW) can be viewed as large trading partners, our framework represents tariff liberalisation with any one or all of these as having similar intra-regional trade and production effects. In practice and at a very fine level of product disaggregation, liberalisation with specific trading partners will have different implications depending upon technology, product design, distribution systems, marketing strategies and so on. Our analysis cannot capture such micro effects, but the assumption that the EU and US are both competitive with local production in the Caribbean is reasonable.

The key differences between the experiments relates therefore to extra-regional 
trade effects. Trade creation resulting from consumption effects will be maximised by multilateral liberalisation, which also minimises trade diversion. Indeed there is no trade diversion and therefore no transfer from the region to 'pay' for extraregional inefficiency in production. Consumer and net welfare gains are maximised, but there is a complete redistribution of government revenue to consumers. Extended reciprocity is an intermediate outcome. On the one hand, there is greater scope for consumption-induced trade creation than restricted reciprocity, but less than for multilateral liberalisation. On the other hand there is less scope with extended reciprocity for trade diversion than with restricted reciprocity. Thus we anticipate greater extra-regional trade expansion, greater fiscal loss and greater consumer and net welfare gains with extended than restricted reciprocity.

Trade Effects: Estimated intra- and extra-regional trade effects are summarised in Table 6. Although there are uniform changes in intra-regional imports across experiments, the shift in the source of supply will be different for each; shifting to the EU, EU and US and ROW for the respective experiments. In addition, extraregional imports expand in each experiment because of expansion of imports from the liberalised source. These grow as the size of the liberalised import base increases. In part $\mathrm{b}$ of Table 6 there is therefore a consistent ranking, with EU-only reciprocity inducing the smallest increase in aggregate and multilateral liberalisation the greatest. In Barbados for example the increase ranges from $7.1 \%$ for restricted reciprocity to $20.1 \%$ for complete liberalisation.

The combined impact of declining intra-regional imports and increasing extraregional imports is represented in part c. There are increases in total imports from all sources associated with all three experiments; the largest, as expected, generated by multilateral liberalisation. For extended reciprocity total imports increase by between $7.5 \%$ (Trinidad) and 11.6\% (Jamaica), and by between 10.8\% (St Vincent) and $16.5 \%$ (Jamaica). Thus, although there is a consistent ordering of the magnitude of the effects across experiments, there is a differential ordering (value and percentage) of trade effects across countries.

Fiscal Effects: Given the dependence on trade taxes in most Caribbean countries, fiscal consequences of adjustment are a sensitive issue. ${ }^{15}$ Table 7 reports

\footnotetext{
${ }^{15}$ For a recent analysis of fiscal dependence on trade taxes in developing countries and the impact of liberalisation see Kattry and Rao (2002).
} 
Table 6. Comparison of Import Effects of Alternative Trade Policy Experiments (By Country)

\begin{tabular}{|c|c|c|c|c|c|c|c|c|c|}
\hline & \multicolumn{3}{|c|}{ a) Change in imports from region } & \multicolumn{3}{|c|}{ b) Change in extra-regional imports } & \multicolumn{3}{|c|}{ c) Change in total imports } \\
\hline & $\begin{array}{l}\text { 1) } \\
\text { EU only } \\
\text { reciprocity }\end{array}$ & $\begin{array}{l}\text { 2) } \\
\text { EU \& US } \\
\text { reciprocity }\end{array}$ & $\begin{array}{l}3) \\
\text { multilateral } \\
\text { liberalisation }\end{array}$ & $\begin{array}{l}\text { 1) } \\
\text { EU only } \\
\text { reciprocity }\end{array}$ & $\begin{array}{l}\text { 2) } \\
\text { EU \& US } \\
\text { reciprocity }\end{array}$ & $\begin{array}{l}3) \\
\text { multilateral } \\
\text { liberalisation }\end{array}$ & $\begin{array}{l}\text { 1) } \\
\text { EU only } \\
\text { reciprocity }\end{array}$ & $\begin{array}{l}\text { 2) } \\
\text { EU \& US } \\
\text { reciprocity }\end{array}$ & $\begin{array}{l}\text { 3) } \\
\text { multilateral } \\
\text { liberalisation }\end{array}$ \\
\hline Barbados & -92.36 & -92.36 & -92.36 & 164.06 & 307.50 & 463.80 & 71.70 & 215.14 & 371.44 \\
\hline Belize & -7.39 & -7.39 & -7.39 & 19.00 & 89.22 & 128.08 & 11.61 & 81.83 & 120.69 \\
\hline Grenada & -37.69 & -37.69 & -37.69 & 49.70 & 86.22 & 105.28 & 12.01 & 48.53 & 67.59 \\
\hline Jamaica & -242.52 & -242.52 & -242.52 & 363.95 & 1148.91 & 1534.51 & 121.42 & 906.39 & 1291.99 \\
\hline Kitts\&Nevis & -17.70 & -17.70 & -17.70 & 24.64 & 54.83 & 73.80 & 6.94 & 37.13 & 56.10 \\
\hline St. Lucia & -49.51 & -49.51 & -49.51 & 70.85 & 123.59 & 164.26 & 21.33 & 74.08 & 114.75 \\
\hline Trinidad & -69.08 & -69.08 & -69.08 & 229.93 & 678.12 & 1137.20 & 160.85 & 609.04 & 1068.12 \\
\hline Belize & -15.70 & -15.70 & -15.70 & 2.50 & 11.80 & 16.94 & 1.50 & 10.43 & 15.38 \\
\hline Dominica & -15.40 & -15.40 & -15.40 & 12.10 & 20.00 & 25.17 & 2.40 & 8.25 & 12.09 \\
\hline Grenada & -15.50 & -15.50 & -15.50 & 12.80 & 22.11 & 27.00 & 2.20 & 8.99 & 12.52 \\
\hline Jamaica & -15.80 & -15.80 & -15.80 & 5.20 & 16.42 & 21.93 & 1.60 & 11.57 & 16.49 \\
\hline Kitts\&Nevis & -15.00 & -15.00 & -15.00 & 7.70 & 17.04 & 22.94 & 1.80 & 9.36 & 14.14 \\
\hline St. Lucia & -15.30 & -15.30 & -15.30 & 10.20 & 17.78 & 23.63 & 2.40 & 8.37 & 12.96 \\
\hline Trinidad & -12.20 & -12.20 & -12.20 & 2.90 & 8.59 & 14.41 & 2.00 & 7.45 & 13.07 \\
\hline St. Vincent & -14.70 & -14.70 & -14.70 & 12.60 & 19.50 & 22.81 & 3.10 & 8.33 & 10.83 \\
\hline
\end{tabular}


Table 7. Changes in Customs Revenue by Country of Alternative Trade Policy Experiments

\begin{tabular}{l|c|c|c|c|c|c}
\hline \multirow{2}{*}{} & \multicolumn{2}{|c|}{ EU reciprocity } & \multicolumn{2}{c|}{ EU \& US reciprocity } & \multicolumn{2}{c}{ multilateral liberalisation } \\
\cline { 2 - 7 } & mEC\$ & $\%$ & mEC\$ & $\%$ & mEC\$ & $\%$ \\
\hline Barbados & -182.4 & -78.1 & -216.14 & -92.6 & -233.4 & -100.0 \\
Belize & -52.33 & -68.0 & -65.87 & -85.6 & -76.9 & -100.0 \\
Dominica & -21.85 & -75.1 & -27.07 & -93.0 & -29.1 & -100.0 \\
Grenada & -31.19 & -74.4 & -39.15 & -93.4 & -41.9 & -100.0 \\
Jamaica & -635.12 & -76.7 & -759.78 & -91.8 & -828.1 & -100.0 \\
Kitts\&Nevis & -25.89 & -73.0 & -32.26 & -90.9 & -35.5 & -100.0 \\
St. Lucia & -60.40 & -76.8 & -71.57 & -91.1 & -78.6 & -100.0 \\
Trinidad & -390.09 & -61.8 & -515.39 & -81.7 & -631.0 & -100.0 \\
St. Vincent & -27.34 & -72.0 & -35.81 & -94.3 & -38.0 & -100.0 \\
\hline
\end{tabular}

these for each country, along with those for the other two experiments. The absolute values reported capture the maximum potential falls of the respective customs authorities. They also assume no tariff redundancy and no attempt to replace import tariffs with (say) consumption taxes. ${ }^{16}$

Extended reciprocity produces intermediate declines in customs revenue, given the initial importance of these import sources for all countries and the considerable scope for switching of imports from dutiable ROW to non-dutiable EU and US. With falls of customs duties of between $81.7 \%$ (Trinidad) and 94.3\% (St Vincent), restricted reciprocity is very similar in its impact effects to complete liberalisation. Note of course that with income and dynamic effects the relative effects may be different. Full multilateral liberalisation must eliminate customs revenue, but restricted and extended reciprocity may have dynamic income effects that influence the dutiable import base in either direction.

Net Welfare Effects: We report net welfare effects for each country in Table 8 (part a). A priori one would expect multilateral liberalisation to be net welfareraising, and reciprocity welfare-raising or lowering. These rankings are confirmed for all countries. ${ }^{17}$ It turns out that both types of reciprocity are net welfarelowering, with the costs of extra-regional trade diversion (source-switching) exceeding the benefits of trade creation. Multilateral liberalisation is unsurprisingly

\footnotetext{
${ }^{16}$ The literature on optimal tax design is an extensive one, see Whalley (1979), Buffie (2001).

${ }^{17}$ This echoes the results that Kose and Riezman (2000) report using CGE modelling to compare RTAs, Customs Unions and multilateral free trade.
} 
Table 8. Summary of Welfare Effects of Alternative Trade Policy Experiments (By Country)

\begin{tabular}{|c|c|c|c|c|c|c|}
\hline & \multicolumn{6}{|c|}{ Change in net welfare } \\
\hline & \multicolumn{3}{|c|}{ (in $\mathrm{mEC} \$)$} & \multicolumn{3}{|l|}{ (as \% of GDP) } \\
\hline & $\begin{array}{l}1) \\
\text { EU } \\
\text { reciprocity }\end{array}$ & $\begin{array}{l}\text { 2) } \\
\text { EU \& US } \\
\text { reciprocity }\end{array}$ & $\begin{array}{l}3) \\
\text { multileral } \\
\text { liberalisation }\end{array}$ & $\begin{array}{l}1) \\
\text { EU reciprocity } \\
\text { only }\end{array}$ & \begin{tabular}{|l|} 
2) \\
EU \& US \\
reciprocity
\end{tabular} & \begin{tabular}{|l|} 
3) \\
Full multileral \\
liberalisation
\end{tabular} \\
\hline Barbados & -131.71 & -65.39 & 29.71 & -2.2 & -1.1 & 0.5 \\
\hline Belize & -43.50 & -10.91 & 7.26 & -2.7 & -0.8 & 0.5 \\
\hline Dominica & -14.96 & -4.56 & 2.77 & -2.7 & -0.8 & 0.5 \\
\hline Grenada & -21.83 & -6.44 & 4.04 & -2.7 & -1.0 & 0.5 \\
\hline Jamaica & -550.31 & -110.51 & 98.92 & -4.5 & -1.0 & 0.8 \\
\hline Kitts\&Nevis & -20.39 & -5.48 & 3.41 & -2.5 & -0.7 & 0.4 \\
\hline St. Lucia & -42.64 & -14.27 & 7.44 & -2.7 & -0.8 & 0.4 \\
\hline Trinidad & -292.90 & -160.65 & 53.17 & -1.9 & -1.1 & 0.3 \\
\hline St. Vincent & -16.36 & -3.64 & 3.20 & -2.0 & -0.4 & 0.4 \\
\hline
\end{tabular}

(i) basis of estimation set out in Table 4

net welfare-improving. As is usually the case, however, these effects are small relative to the value of gross trade and national product, though it should be recalled they exclude any welfare-raising, domestic allocation effects. EU reciprocity generates welfare losses which range from $1.9 \%$ (Trinidad) to $4.5 \%$ of GNP (Jamaica). Welfare losses from extended reciprocity are somewhat less and the range is lower. By contrast, full multilateral liberalisation delivers welfare gains which range from 0.63 to $0.8 \%$ (Trinidad and Jamaica respectively).

\section{Conclusions}

Unreciprocated preferential access has been a feature of the trade policy landscape throughout the post World War II era. Preferences are, however, becoming less pervasive and more targetted. In the context of EU trade relations with ACP trading partners, the European Commission has been pressing for a shift from oneway to reciprocal preferences as a core element of a REPA. The economic effects of reciprocated preferences between RTAs are not straightforward. Some of the standard concepts from customs union theory can be used, but allowing for intraregional effects complicates the analysis. We have developed a number of customs unions concepts to set up a framework for understanding the economic effects of reciprocated preferences and to evaluate their welfare effects in the context of CARICOM. In addition we have used the framework to evaluate the welfare 
effects of alternatives to reciprocated preferences, namely extended reciprocity and full multilateral liberalisation.

Our framework is partial equilibrium and focuses on impact effects. Notwithstanding this, our policy experiments throw up a number of interesting results. First, the net welfare effects of all of the policy changes we simulate are small relative to GDP. This is not surprising, indeed it echoes a common finding in the empirical trade policy literature. Second, there is a clear ordering to the policy changes, with multilateral liberalisation dominating, followed by extended reciprocity and then restricted reciprocity with the EU. Given the differences in trade coverage between the three, this is the ordering one would expect. Third, restricted reciprocity is unambiguously welfare reducing, suggesting that CARICOM countries would be worse off if they entered into a REPA with the EU. Finally, although the net welfare effects are relatively small, they do mask substantial redistributions from producers and governments to consumers, suggesting that adjustment pressures would be non-negligible. Although the magnitudes would be different if other competitive and dynamic effects of trade could be explicitly allowed for, it is not likely that the ranking of the trade strategies considered here would change. It is difficult to imagine that the pro-competitiveness and dynamic benefits of a REPA would be greater than those of more extended forms of trade liberalisation. It may be interesting to apply the framework set out here to evaluate potential trade effects of REPAs between the EU and other groups of ACP countries, to evaluate probable welfare effects elsewhere.

\section{Acknowledgments}

The authors acknowledge comments on an earlier version of this paper from Geoff Reed as well as participants at a Seminar at the University of Kent. Financial support from the Leverhulme Trust under Programme Grant F114/BF is also gratefully acknowledged.

Received 8 September 2006, Accepted 9 October 2006 


\section{Appendix 1: Import demand substitution elasticity values, and tariff rate estimates}

Table 1. Source Substitution and Import Demand Elasticities

\begin{tabular}{|c|c|c|c|c|c|c|c|}
\hline & \multicolumn{2}{|c|}{$\begin{array}{l}\text { Source Substitution } \\
\text { Elasticities }\end{array}$} & \multirow{2}{*}{\begin{tabular}{|l|} 
Import \\
Demand \\
Elasticities
\end{tabular}} & \multicolumn{4}{|c|}{$\begin{array}{l}\text { Estimated Average Extra-Regional Tariff } \\
(\%)\end{array}$} \\
\hline SITC Code & Intra-Region & Extra-region & & Trinidad & Jamaica & Barbados & Other \\
\hline 00 & 2.8 & \begin{tabular}{|l|}
5.6 \\
\end{tabular} & 0.4 & 21.9 & 22.9 & 9.5 & 18.1 \\
\hline 01 & 2.8 & 5.6 & 1.15 & 19.9 & 23.1 & 5.3 & 16.1 \\
\hline 02 & 2.8 & 5.6 & 1.1 & 19.6 & 20.4 & 4.5 & 14.8 \\
\hline 03 & 2.8 & 5.6 & 1.13 & 29.2 & 25.5 & 2.3 & 19.0 \\
\hline 04 & 2.2 & 4.4 & 0.4 & 13.3 & 13.2 & 3.4 & 10.0 \\
\hline 05 & 2.2 & 4.4 & 0.6 & 29.0 & 30.9 & 28.4 & 29.4 \\
\hline 06 & 2.2 & 4.4 & 1.15 & 21.5 & 26.5 & 2.9 & 17.0 \\
\hline 07 & 2.2 & 4.4 & 1.05 & 15.5 & 16.0 & 13.9 & 15.1 \\
\hline 08 & 2.2 & 4.4 & 1.1 & 2.2 & 3.3 & 4.2 & 3.2 \\
\hline 09 & 2.5 & 5 & 1.125 & 17.0 & 20.8 & 15.0 & 17.6 \\
\hline 11 & 3.1 & 6.2 & 1.15 & 16.5 & 26.3 & 27.6 & 23.5 \\
\hline 12 & 3.1 & 6.2 & 1.15 & 21.0 & 20.0 & 11.5 & 17.5 \\
\hline 21 & 2.8 & 5.6 & 0.7 & 9.1 & 4.2 & 12.3 & 8.5 \\
\hline 22 & 2.2 & 4.4 & 0.4 & 2.5 & 3.7 & 1.1 & 2.4 \\
\hline 23 & 1.9 & 3.8 & 1.6 & 5.9 & 8.0 & 12.1 & 8.7 \\
\hline 24 & 2.8 & 5.6 & 1.3 & 5.9 & 7.9 & 5.5 & 6.4 \\
\hline 25 & 2.8 & 5.6 & 1.25 & 0.0 & 0.0 & 0.0 & 0.0 \\
\hline 26 & 2.2 & 4.4 & 1.3 & 0.3 & 0.0 & 2.8 & 1.0 \\
\hline 27 & 2.8 & 5.6 & 0.8 & 0.4 & 0.6 & 0.0 & 0.3 \\
\hline 28 & 2.8 & 5.6 & 0.4 & 1.1 & 2.2 & 0.0 & 1.1 \\
\hline 29 & 2.2 & 4.4 & 0.4 & 4.4 & 6.5 & 6.7 & 5.9 \\
\hline 32 & 2.8 & 5.6 & 1.65 & 11.0 & 8.4 & 1.2 & 6.9 \\
\hline 33 & 1.9 & 3.8 & 1.65 & 11.0 & 8.4 & 8.1 & 9.2 \\
\hline 34 & 2.8 & 5.6 & 1.65 & 11.0 & 8.4 & 4.2 & 7.9 \\
\hline 35 & 2.8 & 5.6 & 1.65 & 11.0 & 8.4 & 1.2 & 6.9 \\
\hline 41 & 2.2 & 4.4 & 1.1 & 23.8 & 21.7 & 8.4 & 18.0 \\
\hline 42 & 2.2 & 4.4 & 1.1 & 23.8 & 21.7 & 8.8 & 18.1 \\
\hline 43 & 2.2 & 4.4 & 1.125 & 23.8 & 21.7 & 8.6 & 18.0 \\
\hline 51 & 1.9 & 3.8 & 1.65 & 0.1 & 0.5 & 0.2 & 0.3 \\
\hline 52 & 1.9 & 3.8 & 1.65 & 0.2 & 1.6 & 0.7 & 0.8 \\
\hline 53 & 1.9 & 3.8 & 1.4 & 8.0 & 10.7 & 2.6 & 7.1 \\
\hline 54 & 2.8 & 5.6 & 1.65 & 7.5 & 7.8 & 4.9 & 6.7 \\
\hline 55 & 2.8 & 5.6 & 1.65 & 13.3 & 20.5 & 12.7 & 15.5 \\
\hline 56 & 1.9 & 3.8 & 1.65 & 0.4 & 0.6 & 0.0 & 0.3 \\
\hline 57 & 1.9 & 3.8 & 1.6 & 7.7 & 11.3 & 4.8 & 7.9 \\
\hline 58 & 1.9 & 3.8 & 1.6 & 7.7 & 11.3 & 5.3 & 8.1 \\
\hline
\end{tabular}


Table 1. Source Substitution and Import Demand Elasticities (Continued)

\begin{tabular}{|c|c|c|c|c|c|c|c|}
\hline & \multicolumn{2}{|c|}{$\begin{array}{l}\text { Source Substitution } \\
\text { Elasticities }\end{array}$} & \multirow{2}{*}{$\begin{array}{l}\begin{array}{l}\text { Import } \\
\text { Demand }\end{array} \\
\text { Elasticities }\end{array}$} & \multicolumn{4}{|c|}{$\begin{array}{l}\text { Estimated Average Extra-Regional Tariff } \\
(\%)\end{array}$} \\
\hline SITC Code & Intra-Region & Extra-region & & Trinidad & Jamaica & Barbados & Other \\
\hline 59 & 1.9 & 3.8 & 1.65 & 2.7 & 4.0 & 2.4 & 3.0 \\
\hline 61 & 4.4 & 8.8 & 1.625 & 10.5 & 15.1 & 14.9 & 13.5 \\
\hline 62 & 1.9 & 3.8 & 1.6 & 5.9 & 8.0 & 12.1 & 8.7 \\
\hline 63 & 2.8 & 5.6 & 1.3 & 5.9 & 7.9 & 6.3 & 6.7 \\
\hline 64 & 1.8 & 3.6 & 1.4 & 6.6 & 8.8 & 2.7 & 6.0 \\
\hline 65 & 3.3 & 6.6 & 1.4 & 7.9 & 9.6 & 5.0 & 7.5 \\
\hline 66 & 2.8 & 5.6 & 2.25 & 10.5 & 10.8 & 7.5 & 9.6 \\
\hline 67 & 2.8 & 5.6 & 2 & 7.2 & 5.2 & 6.7 & 6.4 \\
\hline 68 & 2.8 & 5.6 & 2 & 2.0 & 2.1 & 1.4 & 1.8 \\
\hline 69 & 2.8 & 5.6 & 2.375 & 7.2 & 7.2 & 4.6 & 6.3 \\
\hline 71 & 2.8 & 5.6 & 2 & 2.8 & 2.6 & 2.7 & 2.7 \\
\hline 72 & 2.8 & 5.6 & 3.25 & 2.8 & 2.6 & 2.7 & 2.7 \\
\hline 73 & 2.8 & 5.6 & 2.25 & 2.8 & 2.6 & 2.7 & 2.7 \\
\hline 74 & 2.8 & 5.6 & 3.25 & 2.8 & 2.6 & 2.8 & 2.7 \\
\hline 75 & 2.8 & 5.6 & 3.25 & 10.0 & 10.3 & 5.3 & 8.5 \\
\hline 76 & 2.8 & 5.6 & 3.25 & 10.4 & 10.9 & 4.7 & 8.7 \\
\hline 77 & 2.8 & 5.6 & 3.25 & 10.0 & 10.3 & 5.4 & 8.6 \\
\hline 78 & 5.2 & 10.4 & 2.25 & 10.8 & 8.3 & 26.1 & 15.1 \\
\hline 79 & 5.2 & 10.4 & 2.75 & 3.0 & 2.5 & 6.0 & 3.8 \\
\hline 81 & 2.8 & 5.6 & 2.25 & 5.0 & 7.9 & 7.1 & 6.6 \\
\hline 82 & 2.8 & 5.6 & 1.4 & 17.3 & 21.0 & 9.5 & 15.9 \\
\hline 83 & 3.6 & 7.2 & 2 & 18.0 & 21.8 & 10.9 & 16.9 \\
\hline 84 & 4.4 & 8.8 & 2.5 & 19.9 & 24.7 & 8.5 & 17.7 \\
\hline 85 & 4.4 & 8.8 & 2.5 & 16.3 & 20.0 & 18.9 & 18.4 \\
\hline 87 & 2.8 & 5.6 & 2 & 6.4 & 6.0 & 3.3 & 5.2 \\
\hline 88 & 2.8 & 5.6 & 2.5 & 13.3 & 12.3 & 15.8 & 13.8 \\
\hline 89 & 2.8 & 5.6 & 1.25 & 14.3 & 17.5 & 19.6 & 17.1 \\
\hline
\end{tabular}

\section{References}

Bhagwati, J. Greenaway, D. and Panagariya, A. (1998) 'Trading Preferentially: Theory and Policy', Economic Journal, Vol. 108, pp. 1128-1148.

Bond, E., Riezman, R. and Syropoulos, C. (2004) 'A Strategic and Welfare Theoretic Analysis of Free Trade Areas', Journal of International Economics, Vol. 64, pp. 1-2.

Buffie, E. (2001) Trade Policy in Developing Countries, (Cambridge, Cambridge University Press).

El Agraa, A. and Nicholls, S. (1997) 'The Caribbean Community and Common Market', in El Agraa (ed) Economic Integration Worldwide, (London, Macmillan). 
Francois, J., McQueen, M. and Wignaraja, G. (2005) 'European Union - Developing Country FTAs : Overview and Analysis' World Development, Vol. 33, pp. 1545-1565

Gasoriek, M. and Winters, L.A. (2004) 'What Role for EPAs in the Caribbean?, The World Economy, Vol. 27, pp. 1335-1362.

Hertel, T.W. (ed) (1997) Global Trade Analysis: Modelling and Application, (Cambridge, Cambridge University Press).

Khattry, B. and Mohan Rao, J. (2002) 'Fiscal Faux Pas?: An Analysis of the Revenue Implications of Trade Liberalization'. World Development, Vol. 30, pp. 1431-1444.

Kose, A. and Riezman, R. (2000), 'Understanding the Welfare Implications of Preferential Trade Agreements', Review of International Economics, Vol. 8, pp. 619-633.

Lahiri, S. (ed) (2001) Regionalism and Globalisation, (London, Routledge).

McQueen, M. (1998) 'Lomé versus Free Trade Arrangements: The Dilemma Facing ACP Countries', The World Economy, Vol. 21, pp.421-444.

Milner, C., Morrissey O. and McKay, A. (2005) 'Some Simple Analytics of the Trade and Welfare Effects of Economic Partnership Agreements', Journal of African Economies, Vol. 14, pp. 327-358.

Nicholls, S., Birchwood, A., Colthurst, P. and Boodoo, E. (2000) 'The State and Prospects for Deepening and Widening of Caribbean Integration', The World Economy, Vol. 23, pp. 1161-1194.

Panagariya, A. (1999) 'The Regionalism Debate: An Overview', The World Economy, Vol. 22, pp. 477-512.

Panagariya, A. (2002) 'EU PTAs and Developing Countries', The World Economy, Vol. 25, pp.1415-1432.

Panagariya, A. and Srinivasan, T.N. (1998) 'The New Regionalism: A Benign or Malign Growth', in J. Bhagwati and M. Hirsch (eds) Essays in Honor of Arthur Dunkel (Ann Arbor, University of Michigan Press).

Read, R. (2003) ' The Implcations of Increasing Globalization and Regionalism for the Economic Growth of Small Island States', World Development, Vol. 32, pp. 365-378.

Schiff, M. (2001) Will the Real 'Natural Trading Partner' Please Stand Up? Journal of Economic Integration Vol. 16, pp.245-261.

Viner, J. (1950) The Customs Union Issue (New York, Carnegie Endowment).

Whalley, J. (1987) 'Uniform Domestic Taxes, Trade Distortions and Economic Integration', Journal of Public Economics, Vol. 11, pp. 213-21.

Whalley, J. (1990) 'Non-discriminatory Discrimination: Special and Differential Treatment Under the GATT', Economic Journal, Vol. 100, pp. 1318-28.

Whalley, J. (1999) 'Special and Differential Treatment in The Millennium Round', The World Economy, Vol. 22, pp. 1065-94.

Winters, L.A. (1996) 'Regionalism versus Multilateralism', Policy Research Working Paper 1687) Washington, World Bank.

Winters, L.A. (1997) 'Assessing Regional Integration Arrangements' mimeo, The World Bank.

Winters, L.A. (2001a) ‘Post Lomé Trading Arrangements: The Multilateral Alternative’ in 
von Hagen, J. and Widgren, M. (eds) Regionalism in Europe: Geometries and Strategies after 2000, Kluwer, Dordrecht, pp.221-260.

Winters, L.A. (2001b) 'Regionalism for Developing Countries: Assessing the Costs and Benefits' in ed Lahiri (2001). 